\title{
Human Security and Developmental Crisis in the Contemporary West Africa
}

\author{
Ayodeji A. Aduloju* and Omowunmi O. Pratt \\ Department of International Relations, Obafemi Awolowo University, Ile-Ife, Nigeria; \\ E-Mail: prattomowunmi@gmail.com (OOP) \\ * Corresponding Author: E-Mail: adulojutony@gmail.com; Tel.: +234 8032558219
}

Submitted: 19 March 2014 | In revised form: 24 September 2014 | Accepted: 5 October 2014 |

Published: 30 October 2014

\begin{abstract}
The last two decades were characterized by severe conflicts in the West Africa subregion. The era of conflict resolution, management and peace building thus came to define the region. The destruction left by long years of protracted conflicts and the present state of development is reason enough to warrant attention both from within and beyond. The study expounds, operationalizes and clarifies the concept of human security and development, and how human security issues lead to underdevelopment. The paper investigates the human security concerns in the post-conflict period and also looks at the crisis of development in the sub-region. It highlights details on the developmental crises that have bedevilled the sub-region and at the same time exposes the threats these crises pose on national security and peace in the subregion. This paper concludes that there is no appreciable effort in operationalizing human security in West Africa and this will lead to instability. The paper maintains that human security issues now complicate the developmental crisis in the sub-region due to its ambiguity. The paper suggests that policy makers should address human security issues in order to tackle developmental crisis in the sub-region.
\end{abstract}

Keywords: conflict and wars; development; human security; West Africa

\section{Introduction}

The West African sub-region is potentially one of the richest in the world owing to its large stock of natural resources. The sixteen (16) nations that constitute the region include: Nigeria, Ghana, Togo, Benin Republic, Liberia, Sierra Leone, Senegal, Burkina Faso, Mali,
Gambia, Guinea Bissau, Cape Verde, Mauritania, Côte d'Ivoire, Niger and Guinea. The geographical region of West Africa is one of the poorest regions in the world, due to years of conflicts and instabilities which have impinged on development [1]. What remains of conflict in the sub-region is not guns, bullets, bombs, machetes and other weapons used in propagating conflicts and 
wars, but a huge decline on human and infrastructural development. While conflict has reduced in the region in recent years, the crisis of development which has been known for a long time, aggravated by protracted years of conflicts and sustained by political instabilities, has put the international community on alert. Developmental crises such as increased poverty, hunger, unemployment, indebtedness of government, bad leadership, environmental degradation, etc. are much more visible and define the contemporary West Africa. These concerns continue to pose considerable challenge to national and regional stability as well as to human security [2].

The concept of security today in the international system has taken on different meanings from the traditional approach. This is due to the changing and emerging issues; and challenges in the system that states acquiring military power or engaging in 'hard politics' alone cannot address. Amongst these diverse meanings is the all-encompassing concept of human security. The humanitarian concerns arising from developmental crisis have undermined the protection and empowerment of individuals within the subregion. The collapse of the security system in most West African states through the civil wars in Liberia and Sierra Leone as well as armed attacks in Senegal, Niger, Guinea, Côte d'Ivoire and more recently, Mali, the North-Eastern part of Nigeria has worsened the phenomenon of insecurity amongst the people, leading to developmental crises. It is also imperative to stress that developmental crisis could also lead to human insecurity, as is the case in the Niger Delta region of Nigeria, where severe developmental crises caused armed and guerrilla warfare, thereby aggravating the human insecurity conditions in the region. According to the United Nations Development Programme (UNDP) Human Development Index (HDI), countries in West Africa have been among the least developed countries of the world for decades; with low per-capital income, high poverty levels, high inflation, unemployment and low economic growth [3]. These Human Security concerns have future consequences on national security and prospects of peace in the sub-region.

This paper investigates human security issues in the post-conflict period and also looks at the crisis of development in the West African sub-region. It provides a detailed analysis on the future threats posed by the conflict situation on regional security and peace.

\section{Defining the Contemporary West Africa}

Religion and language (the spatial distributions of which form formal cultural regions) are two of the most central elements of culture. The spatial distributions of religion and language are strong indicators of the distribution of culture. As a result of imperialism, African political boundaries are often incompatible with the spatial distribution of language and/or religion. In other words, cultural groupings are divided by political boundaries. These unnatural divisions are often a source of tension and conflicts [4].

Since the end of the colonial period, West Africa has become one of the most violent places on earth. Many West African nations have witnessed political instability, with notable civil wars in Nigeria, Sierra Leone, Liberia, Côte d'Ivoire, Guinea-Bissau, Senegal, and ethnic tension in Guinea and a succession of military coups in Ghana and Burkina Faso and presently Mali. The origin of conflict in West Africa preceded the legal initiative that brought about the integration of the sub-region through the establishment of Economic Community of the West African States (ECOWAS). Invariably, there were conflicts in West Africa before the idea of economic integration (the Nigerian civil war which began in 1967 and ended in 1970 is a case in point).

As a result of decolonization in Africa in the mid1950 s and late 1970 s, conflicts in West Africa became prominent as a result of the intense ideological rivalry between the Soviet Union and the United States and its allies, who used most African states to engage themselves in conflict by proxy, as seen during the Nigerian Civil war. Not only did they do this, but also scrambled for the natural resources in the sub-region in the 80s and 90s (diamonds in Sierra Leone, oil in Nigeria, gold in Ghana) which meant that both sides supported tyrannical regimes in these countries because of their vested interests. Though these conflicts varied in dimension, duration, scales and intensities, the civil wars in Liberia and Sierra Leone became a challenge for the sub-region and the international community at large due to large scale humanitarian concerns, high level of atrocities committed, inclusion of children in the wars and the influx of refugees into other neighbouring West African countries. At the same time, the trans-border movement and proliferation of small arms and light weapons propelled countries such as Togo, Nigeria, Côte d'Ivoire, Mali and others, to experience infinitesimal form of instabilities. These conflicts and their negative effects on the sub-region led the West African states, under the auspices of the ECOWAS and the international community, through the United Nations to intervene. The ECOWAS and the UN's conflict resolution, management and prevention helped put an end to the era of severe armed conflict in West Africa and have since intervened in the ongoing conflicts in Mali and Nigeria.

Today, the sub-region has transited from the era of civil wars to an era characterised by crises of development, a remnant of the era of armed conflict. The region is ridden with underdevelopment, forced migration, climate change, poverty, famine, drought, rising food prices and declining food stock etc.; which are key factors contributing toward West Africa's food crisis. Fifteen million people across West Africa are directly affected by the food crisis. Severe malnourishment has caused an increase in illness and the death rate in the region. It is also important to note 
that the sub-region is not immune to one of the most pressing issues for human life; the challenge of HIV/ AIDS. This epidemic with a global scope, affects at least 40 million people. The region most severely impacted is sub-Saharan Africa, particularly Côte d'Ivoire, Liberia, and Nigeria [5].

Many other challenges such as human migration, environmental sustainability, illiteracy, unemployment and corruption define the contemporary West Africa. Corruption and underdevelopment have impacted negatively on the health sector. Health is still not 'for all', but rather characterized by glaring inequities among socio-economic groups and classes. Similarly, the adverse impact of climate change poses a further threat to the issue of environmental sustainability and to the achievement of the Millennium Development Goals. This also presents a significant policy challenge for a region that faces huge energy needs to power its development and industrialization [6].

\section{Conceptualizing Human Security and Development}

\subsection{Human Security}

Human security is indivisible. A general dynamic of equitable and balanced development is its best cornerstone. The growing interaction of societies on a worldwide scale increasingly demonstrates the overall need for human security, though it is not yet enough to prevent all forms of violence or conflict. The world's future depends upon a growing need for human security and a better understanding of all the risks and threats that affect populations and individuals [7].

The concept of human security has expanded the notion of security. The traditional notion of security was one where policy makers were more interested in policing their borders to deter external influence and threats. However, due to the changes occurring in the international arena, where states no longer wage war against each other; other emerging issues, threats and challenges have effectively caused states to unite (as against isolationism they employed during the national security era) and pool resources together through joint policy frameworks to tackle these challenges that individual states cannot resolve on their own. Succinctly put, the inadequacies of national security led to the emergence of human security.

While the traditional concept of national security, which dominated the Cold War era, was mainly geared towards the security of states and aimed at protecting their sovereignty and territorial integrity from military threats, the advocates of human security demanded that this traditional notion of security be deepened and widened. Individuals were also to be regarded as being imbued with security, and more attention was to be devoted to their protection. Furthermore, non-military risk factors such as poverty, disease, and political violence were to be taken into greater account [7]. In the nuclear debate, for example, it has been argued that the stability and wellbeing of communities and nations rests as much on factors associated with human development, economic growth, and democracy as on acquisition of a weapons arsenal [8].

This particular concept, 'human security,' is most often associated with the 1994 Human Development Report on Human Security, drafted and championed by former Pakistani Finance Minister Mahbub ul Haq with strong support from economist Amartya Sen [9]. In defining the concept, it should be noted that as with all concepts, there is no universally accepted definition for the term. Different academic discourses have framed the term differently: as a new theory or concept, as a starting point for analysis, a world view, a political agenda, or as a policy framework [10]. Although the definition of human security remains an open question, there is consensus among its advocates that there should be a shift of attention from a state-centred security notion to a people-centred approach to security [10]. It is also imperative to stress that human security is a not a replacement for State security. Rather, it seeks to examine every aspect of human life, taking into account the various possible threats at different levels (local, national and regional). Human security entails a global approach linking security, governance, solidarity and development issues. It addresses security in a broad sense that includes all political, economic, social and environmental dangers [11].

The Human Development Report of 1994 entitled 'New Dimensions of Human Security' was undoubtedly the first attempt to define the concept in a universal way. Human Security is defined in relation to seven dimensions reflecting almost all of the key components of human development [12]. They are:

- Economic security: assured basic income; access to employment and resources.

- Food security: physical and economic access to food for all people at all times. Hundreds of millions of people in the world remain hungry either through local unavailability of food or, more often, through lack of entitlements or resources to purchase food.

- Health security: access to medical treatment and improved health conditions. Poor people in general have less health security, and in developing countries the major causes of death are infectious and parasitic diseases.

- Environmental security: living in a healthy physical environment which is spared from desertification, deforestation and other environmental threats that endanger people's survival.

- Personal security: individual security from physical violence. Threats can take several forms, for example: threats from the State, foreign states, other groups of people (ethnic tension), individuals or gangs; threats directed against women or children based on their vulnerability and dependence; 
threats to self (e.g. suicide, drug use, etc.).

- Community security: most people derive their security from membership of a social group (family, community, organisation, political grouping, ethnic group, etc.). Tensions often arise between these groups due to competition over limited access to opportunities and resources.

- Political security: living in a society that guarantees basic human rights and freedom of expression [13].

This definition of security was therefore 'peoplecentred' and 'universal,' and also consisted of 'interdependent' components. To establish this concept 'through early prevention,' the report advocated the use of early warning indicators of human distress such as crime rates, road traffic accidents, pollution, and income inequality [14]. These indicators are now regularly incorporated in the annual issues of the UNDP Human Development Report [15].

According to Akokpari [16], the fundamentals of human security have been captured in a poetic, yet practical way by Pettman [17]. Pettman believes Human Security is;

about the young child that did not die of neglect, the serious epidemic that did not break out, the job that was not cut, the gun that was not run, the ethnic prejudice that did not result in violence, the dissident voice that was not made silent, the landmine that was not sold and installed, the woman who was not trafficked across state borders and sexually abused, the agricultural product that was not dumped to the detriment of the poor farmers, the short-term capital investment that was not allowed to wreck an infant industry, the addictive product that was not produced and shipped, the refugee that was not forced to flee and remain abroad and so on ([17] p. 140).

In short, human security is about eradicating threats to dignified life that characterise contemporary society; it is about securing life free from threats [16].

Human security for the former UN Secretary General Kofi Annan is an objective link that binds globalization and international governance. In his 3rd of April, 2000 Action Plan for the 21st century, he emphasized that globalization had to emerge as a positive force for people all over the world. It had to help in building a better world for all of humanity. A world where the wellbeing of humans will be at the core of all policies, be it social, economic, political, security etc., in order to prevent the outbreak of conflict. He combined the total fulfilment of three fundamental human rights in his formulation of the notion of human security:

- The right to freedom of want

- The right to freedom of fear and

- The right of future generations to inherit a healthy planet $[18,19]$.
While freedom from physical hurt, injury, abuse or threat constitutes the core of individual security, academic views of how the communal concept of human security should (or could) be expanded from this core differ sharply. For some, hunger, disease and environmental contamination represent grave security threats-even worse than physical violence. Thus, conditions of abject poverty or powerlessness are viewed as not qualitatively different from vulnerability to physical violence during conflict. Others have argued that human security should include the notion of 'structural violence,' referring to the structure of the relevant political-social system (such as apartheid) or the global trading system [20].

Fung [20] in his work brought to the fore the perception of Frederico Mayor, the former UNESCO Director General, who perceived Human Security to coincide with the 'protection' and 'defence of human dignity' in all circumstances. In this perspective, human security therefore becomes identified with the defence of human rights, which are universal and indivisible in their very essence. With this thought in the mind of Mayor, it is therefore the responsibility of the United Nations to promote human security in all its facets in the five continents. He further states that 'human security' consists of preserving international stability on the basis of the promotion of values such as:

- The supremacy of the law

- The respect for democracy

- The defence of human rights

- Equality before the law

- Good public affairs management

- The peaceful resolve of conflicts and

- The protection of the environment, etc.

The United Nations Commission on Human Security defines human security as the effort by states and organizations to protect the vital core of all human lives in ways that enhance human freedoms and human fulfilment as well as empowering people to provide and care for themselves. Specifically, it entails creating systems that provide people the foundation for survival, dignity and livelihood. This definition encompasses the two core strategies of human security: protection and empowerment of people [21].

In simple terms therefore, this concept emphasizes that in order for people to be secure, their lives must be free from any pervasive threats (violent or benign) to their rights and their safety. It thus encompasses both the traditional and non-traditional threats to people's security [12]. The threat range includes the following:

- Economic threats

- Food threats

- Health threats

- Environmental threats

- Personal threats

- Community threats 
- Political threats

- Gender-based threats

- Demographic threats

- Crime in all forms, including terrorism

- Natural disasters

- Violent conflicts and wars

- Genocide

- Anti-personnel mines, Small Arms and Light weapons (SALW), etc. [22].

Human security represents an effort to reconceptualize security in a fundamental manner. It is primarily an analytical tool that focuses on ensuring security for an individual, not the state. As noble as this concept is, it has not been void of criticism since it gained prominence in international politics. Human security, some argue, is merely 'old wine in new bottles,' combining traditional concerns about 'freedom from fear' and 'freedom from want.' The former addresses political liberties and the latter economic entitlements, roughly parallel to the first and second generation of human rights. Others argue that the concept is 'too idealistic,' and fails to consider the real-world politics of geopolitical power in a rapidly changing international system [23].

In further conceptualization of the concept, it is important to state that there are at least two approaches to understanding human security. The narrow school, which is associated with Canada and, to a certain degree, with the Human Security Network [24]. Fundamentally, this school argues that the threat of political violence to people, by the state or any other organized political entity, is the appropriate focus for the concept of human security $[25,26]$. This perspective is mainly linked to the idea of freedom from fear.

The broad school argues that human security means more than a concern with the threat of violence. Human security does not only entail freedom from fear, but also freedom from want. This perception is associated with Japan, the Commission on Human Security [21] and the United Nations Trust Fund for Human Security. More recently, it can be argued that a third perspective or a second generation of human security i.e. the European school, is evolving which encompasses both the narrow and the broad school $[27,28]$.

Human security appears to appeal to 'middle powers' neither the most powerful nor the weakest states. When the UNDP definition of human security was put up for discussion at the Copenhagen Social Summit in 1995, no formal consensus was reached. Although the conference's declarations included a commitment to 'promoting social integration by fostering societies that are stable, safe and just,' the proposed human security definition was perceived at the Summit as too broad, too idealistic, and as threatening traditional concepts of national security. The negotiations concentrated on striking a balance between national sovereignty and global action: the EU countries argued for increased leverage was only sought on national policies in the name of social development, while the G-77 countries held firmly to the importance of 'territorial integrity and noninterference,' which the universal and all-encompassing elements of human security appeared to undermine.

Perhaps the strongest argument against the concept is its vagueness and breadth. If human security is comprehensive, it may be impossible to prioritize policies and actions. A series of associated terms have developed; people's security, the security of displaced people, livelihood security, environmental security, comprehensive security, and health security. How can all of these insecurities be grouped into a single concept? Which of these threats should be prioritized? Can any be excluded? A deep understanding of the Human security concept, its various components, its interplay with other political concepts and its peculiar nature (if any) in the West African sub-region may be required in charting future perspectives and priorities towards addressing the emerging issues and challenges to peace and security in the West African sub-region.

\subsection{Development}

'Development' is a concept that is contested both theoretically and politically, and is inherently both complex and ambiguous [29]. It would be an understatement to say that the definition of 'development' has been controversial and unstable over time. Gore [30] notes that in the 1950 s and 1960s a 'vision of the liberation of people and peoples' dominated the discourse on development, based on 'structural transformation.' This perception has tended to 'slip from view' for many contributors to the development literature. A second perspective is the definition embraced by international development donor agencies that Thomas notes as a definition of development which is directly related to the achievement of poverty reduction and of the Millennium Development Goals (MDGs) [31].

There is a third perspective by a group of writers that Hickey and Mohan identified as 'post-modernists.' The 'post-modern' position is that 'development' is a 'discourse' (a set of ideas) that actually shapes and frames 'reality' and power relations. It does this because the 'discourse' values certain things over others ([32] p. 38). A common theme within most definitions is that 'development' encompasses 'change' in a variety of aspects of the human condition. Indeed, one of the simplest definitions of 'development' is probably a notion of 'good change,' although this raises all sorts of questions about what is 'good,' what sort of 'change' matters (as Chambers acknowledges), the role of values, and whether 'bad change' is also viewed as a form of development [33]. Although the theme of 'change' may be overriding, what constitutes 'good 
change' is bound to be contested, as Kanbur states, because 'there is no uniform or unique answer' [34]. Views that may be prevalent in one part of the development community are not necessarily shared by other parts of that community, or in society more widely.

Until fairly recently great reliance was placed on GNP per capita as a convenient index of development. It was useful as a compact indicator to policy makers and provided a quantifiable measure for economists who were able to monitor its fluctuations and analyze changes due to movements in sectoral output, factor shares or categories of expenditure. Yet, experience has shown that increases in national income do not necessarily lead to the solution of social, economic and political problems. They remain, perhaps emerging in different forms and changing their dimension in countries with rising per capita income. Indeed, not only does economic growth often fail to resolve social, economic and political difficulties, certain types of inappropriate growth may actually initiate and promote them. It should be recognized that we cannot avoid making value judgements when it comes to defining a more comprehensive index of development. But whose value judgements are to be accepted? One approach would be to copy the path of industrial countries, but which of the currently rich and developed countries appear as really desirable models? Some Western countries with seemingly high incomes cannot be recommended, owing to the damage to the ozone layer from the release of industrial gases into the atmosphere and the likely consequences through global warming for all of us, particularly in the Pacific. The widespread exposure to the modern diseases of cancer, coronary heart disease and other health problems related to high intakes of artificial foodstuffs, over-reliance on politically unstable countries for strategic raw materials (e.g. oil), which often contributes to internal crisis stemming from theses unstable countries, with a spiralling effect on other regions surrounding them, are all pointers to the imperfect nature of their developmental models [35].

For a region to be termed developed, certain conditions should be attained by its citizens, to be precise, enough food and other basic goods and services, (human beings are required to consume a certain amount of calories per day), minimum levels of clothing, footwear and shelter, etc. The failure of a state to attain such an income level which allows the consumption of the minimum nutritionally determined level of food intake would warrant its citizens to be considered destitute and in absolute poverty. Another basic necessity, and a precondition for gaining enough income to rise above the poverty line, is access to a job or some form of employment, which may entail formal paid employment, unpaid work on a family farm or in a family business, or caring for children and members of the household i.e. unpaid household work. The lack of an income-generating opportunity implies labor market inactivity and unemployment, and may lead to poverty. Even when a country realizes a high rate of economic growth, it may fail to reduce poverty and underemployment, since the growth process it is following (e.g. urban-based, import-dependent industrialization) is leaving the majority of the population untouched. Meanwhile, in some parts of Asia and the Pacific, Latin America and in sub-Saharan Africa, because population growth rates are so high, rates of economic growth and employment creation would need to be unprecedented to prevent rising numbers of households falling into poverty. In many Pacific island countries population growth rates exceed the recently attained rate of economic growth, and many households fail to realize any income growth [35].

The obvious direct link between per capita income and the numbers living in poverty is via the distribution of income. Clearly, poverty will be reduced much more rapidly where the fruits of economic growth are accompanied by their more equal distribution, yet, some would argue that equality should be considered a development objective in its own right, and that large scale inequality and massive poverty are objectionable by any religious or ethical consideration. Who could possibly defend the continuance of the existing situation whereby the average American is 117 times richer (in income terms) than the average African? Yet, the true fulfillment of human potential requires more than the above. In addition, a range of levels of basic needs, encompassed under the umbrella term 'social indicators,' need to be satisfactorily provided. They include adequate levels of education (especially literacy and numeracy), food security and nutrition (particularly of young children), mortality, life expectancy and morbidity, and access to a whole range of social services such as health, safe water, sanitation, transportation and housing. In addition, development requires a breakdown of traditional sex roles so that women can also realize their full human potential and gain the ability to freely determine-through access to family planning servicesthe number of children to which they give birth [35].

Furthermore, he stressed that dissatisfaction with GNP as an indicator of development has led to an interest in alternative indices of the 'quality of life.' A 'Physical Quality of Life Index' (PQLI) is usually composed of a composite of three indicators: life expectancy, infant mortality, and literacy. It is often presented as a measure of how effectively various development strategies distribute the benefits of progress to the various component parts of society. The latest version of a PQLI is that of the United Nations Development Programme (UNDP) which was unveiled in 1990 and has brought into existence 'human development' and more recently 'sustainable development.' It argues that 'human development is a process of enlarging people's choices.' These critical choices concern a long and healthy life, education and access to scarce resources [14-35].

In recent times, 'development' has been explained 
using 'human development' and 'sustainable development.' Recent United Nations documents emphasize 'human development,' measured by life expectancy, adult literacy, access to all three levels of education, as well as people's average income, which is a necessary condition of their freedom of choice. In a broader sense the notion of human development incorporates all aspects of individuals' well-being, from their health status to their economic and political freedom. According to the Human Development Report 1996, published by the United Nations Development Program, 'human development is the end-economic growth a means' [36].

According to the Report, human development is defined as 'a process of widening the range of people's choices.' And human security means 'that people can exercise these choices safely and freely-and that they can be relatively confident that the opportunities they have today are not totally lost tomorrow.' The latter is 'a critical ingredient of participatory development.' If given the opportunities to meet their most essential needs and to earn their own living, people will set themselves free and ensure that they can make a full contribution to developments of themselves, their local communities, their countries and the world [15]. In this way, the Report explains that the concept of human security advanced from the perspective of development with special reference to its four characteristics: universal concern, interdependent, ensured by early prevention and people-centered [37].

Sustainable development is a term widely used by policy makers all over the world, even though the notion is still rather new and lacks a uniform interpretation. Important as it is, the concept of sustainable development is still being developed and the definition of the term is constantly being revised, extended, and refined. According to the classical definition, given by the United Nations World Commission on Environment and Development in 1987, development is sustainable if it 'meets the needs of the present without compromising the ability of future generations to meet their own needs.' It is usually understood that this 'intergenerational' justice would be impossible to achieve in the absence of present-day social justice, if the economic activities of some groups of people continue to jeopardize the well-being of people belonging to other groups or living in other parts of the world [38].

Social justice defined as equality of opportunities for well-being, both within and among generations of people, can be seen as having at least three aspects (in no particular order) economic objectives that include growth, efficiency and stability, environmental sustainability that aims to foster a healthy environment for all humans, ensure the rational use of renewable natural resources and the conservation of non-renewable natural resources and finally the social objectives that seek to promote equity, participation, cultural identity, social cohesion and social mobility. Ultimately, only development that manages to balance these three groups of objectives can be sustained for long [38]. Conversely, ignoring one of the aspects can threaten economic growth as well as the entire development process.

\section{Problematizing Human Security and Development in West Africa}

Human Security as a concept offers a better explanation for the causes and solutions to the phenomenon called conflict and war. Since the end of colonialism, states in the sub-region have had the legal rights, under various international agreements to go to war in order to protect their statehood (national security). The post-colonial regimes in the sub-region have witnessed different degrees of insecurity such as political instabilities, coup d'état, resource based conflict and recently, environmental concerns such as climate change, natural disaster and desertification, which poses new threats in the region. The examples of the Fulani herdsmen migrating and encroaching on the farm land of the Tiv tribe in Benue state of Nigeria have resulted in multiple crises over the years and more recently, the rapid shrinking of Lake Chad a source of freshwater servicing about 20 million people, cutting across four countries (Chad, Niger, Nigeria and Cameroon) has been responsible for causing droughts which lead to bad harvests, to destruction of farms and homes by floods etc. This is a major concern for the international community. The UN Food and Agriculture Organization (FAO) have called the situation an 'ecological catastrophe' because the impact of the drying lake is causing tensions among communities around Lake Chad. There are repeated conflicts among nationals of different countries over control of the remaining water. Cameroonians and Nigerians in Darak village, for example, constantly fight over the water [39]. In order to problematize Human Security, it is important to understand the causes of past and new conflicts in West Africa.

\subsection{Causes of Past Conflicts}

After the colonial era, states in the West African subregion plunged into decades of conflict. Most of the conflicts recorded in the sub-region were intra conflict and virtually all countries in the sub-region have been involved in fighting at one time or the other. Over the years, these violent conflicts have called for global intervention due to their grave humanitarian crises. For instance, the Nigerian civil war, Liberian civil war, Ivorian civil war, Sierra Leonean civil war, the NigerDelta crisis in Nigeria, etc. have resulted in lasting negative effects on peace and development in the sub region. According to Adeleye [40], sources of conflict in Africa are boundaries, bad governance and low economic development.

The boundary related conflicts in West Africa were the product of the Berlin Conference of 1884 and the 
Scramble for Africa, where the former colonial powers shared the boundaries in Africa indiscriminately according to their interests [41]. At the end of colonialism there were clear indications that boundaries in West Africa were ill-defined. This restricted the traditional movement of people and also brought people of different origins and ancestral history together. This led to inter-tribal conflicts in the post-colonial states in West Africa. The Nigerian civil war is a case in point. Again, the ill-defined boundaries have led to boundary disputes between Nigeria and Cameroon. Governance conflicts in the sub-region were the result of huge violations of human rights, corruption, marginalisation, nepotism etc., which resulted in violent demands for democracy, coup d'état and counter coup in Côte d'Ivoire, Nigeria, Liberia and Sierra Leone. Low economic development in most West African states led to the World Bank and International Monetary Fund bailout with its stringent conditions, which complicated development in the region and led to high inflation rates, poverty and unemployment. According to Olonisakin [42], the structural causes of conflict in West Africa are weak democratic structures, spatial inequality and social exclusion, level of economic development and distribution, management of natural resources, land allocation and management. These causes of conflicts in West Africa have begot civil strife, recruited youths as militias to resist marginalization and demand equality and development.

\subsection{New Conflicts in West Africa}

Presently, there is an appreciable reduction in large scale violent conflict and civil strife in West Africa: 'pockets of simmering tensions, insurgencies and the re-emergence of coups d'état continue to trouble the sub-region' [43]. The Boko Haram uprising in the North-Eastern part of Nigeria, the recent crisis in Mali which threatens peace and security in the sub-region, the civil war in Côte d'Ivoire and the Niger-Delta oil conflict are all examples of recent conflicts in the subregion. These pockets of crisis have grave implications for the sub-region because their causes are deeply rooted in previous conflicts. Significantly, the proliferation of small arms and light weapons has propelled these recent conflicts. The Boko Haram uprising in the North-Eastern Nigeria can be likened to a war due to high humanitarian problems such as high death rates and the destruction of both local and international infrastructures (the bombing of the United Nations building in Abuja and the Nigerian Police headquarters). This crisis has also affected Nigeria-Cameroon relations as Nigeria recently closed its northern borders with Cameroon to shut out the Boko Haram terrorists that use the borders as launch pads for attacks.

Furthermore, another challenge facing West Africa is that of climate change and natural disasters. Though it is acclaimed that the era of conflict left a huge humanitarian crisis like poverty, proliferation of small arms, underdevelopment, poor public infrastructure, low life expectancy, etc., the crisis of environmental insecurity seems worse. Today, sea levels are rising, deserts are encroaching, flooding and erosion are leading to shortages in food supplies and famine, forced migration of people in the sub-region leading to a refugee crisis. Though the integrating legal framework in the subregion: the Economic Community of West African States (ECOWAS) made provisions in its treaty for the free movement of goods and persons; the treaty does not make provisions for the social well-being of the citizens of the region.

In summary, it is noticeable that the causes of past and new conflicts in West Africa are inadequacies in people-oriented security frameworks or policies. If the concept of hman security brings together economic security, food security, health security, environmental security, personal security, community security and political security; their absence may be the main cause of conflicts in West Africa. In spite of the democratic regimes, people are still marginalized politically: electoral crises after elections are common in Nigeria, Côte d'Ivoire and Togo. The ideas of the right to freedom from want, right to freedom from fear and right of future generations to inherit a healthy planet [20] are not visible. Instead, people across the region are living in fear and want and there is no visible plan for the next generation.

\subsection{Developmental Consequences of Conflicts in West Africa}

The developmental wreckage as a result of conflicts cannot be over-emphasized due to its devastative nature. In West Africa, the raison d'état of most conflicts is the absence of the standard means of measuring qualitative well-being, which contributed to the failures of some states in the past. Though the many years of colonialism played a part in the underdevelopment of the sub-region, as expounded by Walter Rodney in his work 'How Europe Underdeveloped Africa,' the long years of conflict in West Africa can be blamed on how the sub-region underdeveloped itself. Development brings about 'good change' in all strata, security of lives and properties, and effective maintenance of social amenities, however the reverse is the case in West Africa.

According to the United Nations Development Programme (UNDP) Human Development Report, the West Africa sub-region is the world's least developed region. The Human Development Report of the UNDP has over the years become a reference for measuring countries' standard and uses indices such as health, education, social integration and security, environment, population trend and multidimensional poverty indices to measure development. The data below show the Human Development Index trends for countries in West Africa from 1980 to 2013, and also show their 2013 ranking on the global developmental chart. 
Table 1. Human development index (HDI) trends for countries in West Africa, 1980-2013.

\begin{tabular}{lrrrrrrrrr}
\hline Country & 1980 & 1990 & 2000 & 2005 & 2007 & 2010 & 2011 & 2012 & 2013 \\
\hline Benin & 0.253 & 0.314 & 0.380 & 0.414 & 0.420 & 0.432 & 0.434 & 0.436 & 0.476 \\
Burkina-Faso & - & - & - & 0.301 & 0.314 & 0.334 & 0.340 & 0.343 & 0.388 \\
Cape Verde & - & - & 0.532 & - & - & 0.581 & 0.584 & 0.586 & 0.636 \\
Gambia & 0.279 & 0.323 & 0.360 & 0.375 & 0.383 & 0.437 & 0.440 & 0.439 & 0.441 \\
Ghana & 0.391 & 0.427 & 0.461 & 0.491 & 0.506 & 0.540 & 0.553 & 0.558 & 0.573 \\
Guinea & - & - & - & 0.331 & 0.342 & 0.349 & 0.352 & 0.355 & 0.392 \\
Guinea-Bissau & - & - & - & 0.348 & 0.355 & 0.361 & 0.364 & 0.364 & 0.396 \\
Côte d'Ivoire & 0.348 & 0.360 & 0.392 & 0.405 & 0.412 & 0.427 & 0.426 & 0.432 & 0.452 \\
Liberia & 0.298 & - & 0.304 & 0.301 & 0.334 & 0.367 & 0.381 & 0.388 & 0.412 \\
Mali & 0.176 & 0.204 & 0.270 & 0.312 & 0.328 & 0.344 & 0.347 & 0.344 & 0.407 \\
Mauritania & 0.340 & 0.357 & 0.418 & 0.441 & 0.454 & 0.464 & 0.464 & 0.467 & 0.487 \\
Niger & 0.179 & 0.198 & 0.234 & 0.269 & 0.278 & 0.298 & 0.297 & 0.304 & 0.337 \\
Nigeria & - & - & - & 0.434 & 0.448 & 0.462 & 0.467 & 0.471 & 0.504 \\
Senegal & 0.322 & 0.368 & 0.405 & 0.441 & 0.454 & 0.470 & 0.471 & 0.470 & 0.485 \\
Sierra Leone & 0.255 & 0.247 & 0.244 & 0.315 & 0.331 & 0.346 & 0.348 & 0.359 & 0.374 \\
Togo & 0.357 & 0.382 & 0.426 & 0.436 & 0.442 & 0.452 & 0.455 & 0.459 & 0.473 \\
\hline
\end{tabular}

Source: [3].

Table 2. West African countries human development index (HDI) for 2013.

\begin{tabular}{lr}
\hline Country & HDI Rank (2013) \\
\hline Benin & 165 \\
Burkina-Faso & 181 \\
Cape Verde & 123 \\
Gambia & 172 \\
Ghana & 138 \\
Guinea & 179 \\
Guinea-Bissau & 177 \\
Côte d'Ivoire & 171 \\
Liberia & 175 \\
Mali & 176 \\
Mauritania & 161 \\
Niger & 187 \\
Nigeria & 152 \\
Senegal & 163 \\
Sierra Leone & 183 \\
Togo & 166 \\
\hline Source: [3]. & \\
\hline
\end{tabular}

The scale value of UNDP HDI is 1.00 , out of which developed countries like Norway, Australia, United States, Canada, Sweden and Ireland fall within the
HDI range of $0.9-1.0$, while countries in West Africa are between 0.3 and 0.5 (Sierra Leone had a HDI index less than 0.2 during its civil war). The HDI 
values and the 2013 development ranking of the UNDP indicate that the most impoverished countries of the world are mainly found in the sub-region. From the current ranking of Ghana and Cape Verde it can be inferred that the relative stability (through governmental affirmative action towards human security) that Cape Verde has experienced over the years and that of Ghana in recent years have contributed immensely to the visible developmental progress. Ghana, categorized amongst the low developing countries of the world in 1980 with HDI index of 0.391, had achieved astounding progress by 2013 with an HDI index of 0.573 that positioned it as medium developed country and ranked it as the 138th country in the global ranking of human development. Niger's HDI trend of 0.179 in 1980 to 0.337 in 2013; and its 187th position in the global ranking of human development can be linked to series a of Tuareg invasion of the 1990's and series of conflicts associated with electoral crises that ended in 2010. The Malian state has still not recovered from the developmental crisis the conflict created.

According to a report of the Danish Refugee Council (DRC) [44], humanitarian crises like food shortage and insecurity, forced displacement, water shortage and outbreak of diseases are resurfacing in Guinea as a result of inter-ethnic violence, leaving in its wake approximately 30'000 people that have been displaced, dozens of civilians who have died and the destruction of several infrastructures. Also, the DRC monitoring team in Northern Nimba, Liberia; has also identified recent movements of Guineans including cases of separated children who left the country due to continuous hostilities and increased tensions in Nzerekore [45]. In summary, a detailed review of the history of instabilities in each West African state resulting from Human insecurity will provide a glaring linkage between such instabilities and the developmental crises that abound in the sub-region.

\section{Human Security Issues and Developmental Crises in West Africa: Interface and Interchange}

\subsection{The Interface}

It has been established in the previous sections of this work that human security is human centred. This explains the security demands of this contemporary international system to think of the protection of individuals rather than the states. The major causes of internal crises are largely the ones that affect the livelihood of individuals (human insecurity) within the states, rather than the state itself. The final outcome of insecurity (war and conflict) leads to heighten developmental crises such as inadequate social infrastructure, poor health, high illiteracy rate, high inflation rate, debt burden, unemployment, food crisis, famine, outbreak of diseases, forced migration, poverty, political disenfranchisement, election rigging, marginalization etc. Human insecurity issues in West Africa have resulted in civil wars in Nigeria, Sierra Leone, Liberia, Togo, Mali, Côte d'Ivoire, Guinea, Guinea-Bissau and the Gambia, which further caused underdevelopment, or put differently, developmental crises. In Liberia and Sierra Leone for instance, the conflicts left behind underdevelopment tendencies such as forced migration, poverty, food shortage and the outbreak of diseases (e.g. HIV/AIDS, Polio, Malaria, Cholera etc.). Furthermore, the UNDP report in 2001 claimed that Sierra Leone had the world's lowest GDP per capital, which stood at 448 USD, Mali 753 USD and Guinea Bissau 678 USD compared to Luxemburg with $42 ' 769$ USD [46]. In this same year, the UNDP was unable to get data on Liberia because it was embroiled in conflicts that nearly collapsed its sovereignty.

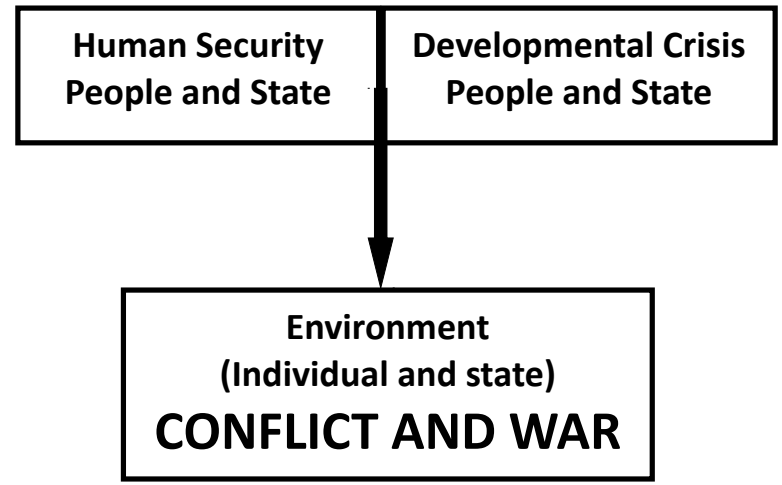

Figure 1. The interface between human security and developmental crises.

The interface between human insecurity and developmental crises is that they affect people, as well as the state and its citizens, and the aftermaths of both have adverse effect on the state and the people. Human insecurity leads to developmental crises vice versa. When policies directed towards achieving the broad human security objectives of freedom from 'want' and 'fear' are operationalized and achieved, this will lead to development. Also, human insecurity and developmental crises lead to conflicts and wars since individuals can take up arms or revolt if their basic needs are not provided. While developmental crisis is not human insecurity and human insecurity is not developmental crises, they both have the same con- 
sequences (conflict and war) on both individuals and state.

\subsection{The Interchange}

The aftermath of past and causes of present crises in West Africa have revealed that human insecurity and developmental crises can switch place. Both are human centred with the ability to cause conflicts and can alternate with the other to be effective in solving humanitarian concerns. In conflict and war scenarios in West Africa, the objectives are shaped by human insecurities and developmental crises. Developmental crises can swap places with human insecurity in order to justify conflict or war, while the end of conflict and war leads to developmental crises. This is not to say that both cannot occur together during conflict, but when one is used as motive for conflict, the other will further explain the devastating effect of conflict.

For instance, the neglect of its citizens by the Nigerian government in the wealth distribution and development in the oil-rich Niger Delta region has led to conflict between the people of the region and the State. The fundamental issues behind the conflicts are related to human security concerns such as environmental pollution and despoliation, disempowerment and subjugation, marginalization and exclusion. Long years of oil exploration in the region created huge environmental disaster for the oil pro- ducing communities, through oil-spillage. This impinged on their access to drinkable water, green environment and at the same time made fishing and farming, which are their main occupations difficult. This caused pervasive poverty and the underdevelopment of the region. The situation got worse in November 1999 when the former president of Nigeria ordered military action on Odi community in Bayelsa state [46]. The employment of military action proliferated militant groups, and caused combustion of armed attacks on the state and oil companies, hostage taking and vandalism of oil installations. In 2009, the then president late Musa Yar'Adua granted amnesty to repentant militants with a promise to develop the region.

From the example given above, it is evident that while human insecurity started in the form of environmental pollution and ethnic marginalisation, developmental crises like poverty and unemployment food crises were the outcome. Human security created a developmental crisis; their heightened level due to negligence created armed conflict, which later made the region volatile and underdeveloped. The level of interchange is at the point of justifying the motive for attacks and kidnappings (human insecurity). While the amnesty granted by the government is a policy agreement of rapid human development in the region. Human security and development crisis interchange in order to understand conflict and post-conflict period.

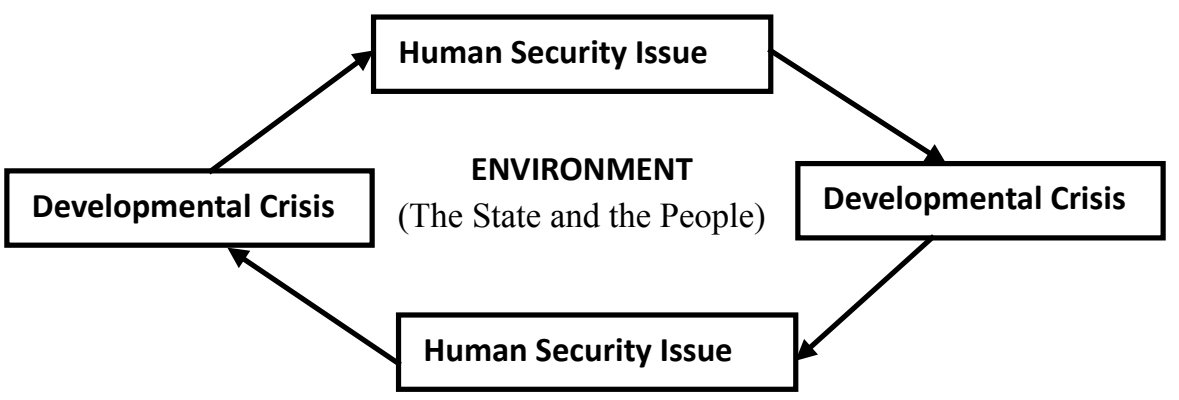

Figure 2. Interchange between human security and developmental crises.

In other words, the interchange explains how human security issues and developmental crises revolve around the same environment in order to define and justify conflict or war and developmental crises.

\section{Security and Development in West Africa: A Conclusion}

Human security and development is people centred, multidimensional, interconnected and universal. In principle, human security and development reflects the aggregate gains as a result of the mitigation of each and every factor that contributes to insecurity. In practice, there is need to focus on a core of insecurities and developmental crisis within each specific context. For the concept of human security and development to thrive, it must be operationalized, applied and enjoy global acceptance.
Consequently in West Africa, conflict and war are interrelated. The states of the sub-region have influenced and can still influence the shape of future conflicts and wars. Human security and development should involve policies that can address democratic governance, transnational crimes, human rights, refugee crisis, poverty, unemployment, socio-economic exploitation, basic needs, public health issues and civil unrest arising from ethnic identities, greed and grievance. Human security and development formulas should extend to internal security, because the region is now plagued with pockets of conflicts within the state. Providing national security alone does not ensure internal peace; there is need to shift from state-centric security and development to re-thinking the people as the central security concern. In all, human security includes what we have understood as humanitarian aid, peace and stability, which brings sustainable development. 
Finally, human security and development provides a holistic approach to promoting peace. In other words, the presence of human insecurity automatically translates into developmental crisis and vice versa. Using development-security nexus is in line with the modern approaches and debate on human security and development will provide a basis for the deeper understanding of the concepts at the international level. Despite being broad, and given the challenges from other schools of thought, the human security and development paradigm provides an ideal shift in understanding peace, security and conflict transformation. Peace may not necessarily mean absence of war, but attaining human security and development would mean promoting a stable environment [47]. In various states where conflicts have ended or are boiling underneath, there is the need to adopt the development-security nexus to tackle the menace.

As a final point and result, this paper highlights how human security issues complicate developmental crisis in West Africa due to its ambiguity. The paper suggests

\section{References}

[1] Kaba AJ. The Two West Africas: The Two Historical Phases of the West African Brain Drain. The Journal of Pan African Studies. 2007;1(8)77-92.

[2] Beckitt P, Bakrania S. Global Facilitation Network for Security Sector Reform (GFN-SSR). Regional Guide: Security Sector Reform in Latin America and the Caribbean. 2010.

[3] UNDP. International Human Development Indicators. Human Development Report 2013. The Rise of the South: Human Progress in a Diverse World. United Nations Development Programme; 2014. Available from: http://hdr.undp.org/en/countries.

[4] Brown BJ, LeVasseur ML. Content Guide: Contemporary Issues of Africa. 2006. Available from: www.nationalgeographic.com/geographyaction.

[5] Oxfam International. Food Crisis in Sahel. 2012. Available from: http://www.oxfamamerica.org/ explore/stories/sahel-food-crisis-where-are-we-at-theend-of-2012/.

[6] Farah I, Kiamba S, Mazongo K. Major challenges facing Africa in the 21st century: A few provocative remarks. International Symposium on Cultural Diplomacy in Africa-Strategies to confront the Challenges of the 21st Century: Does Africa have what is required? Berlin, Germany, 14-17 July 2011.

[7] United Nations Educational, Scientific and Cultural Organisation (UNESCO). Agenda for Action of the International SecuriPax Network for the Promotion of Human Security and Peace; 2000. Available from: http://www.unesco.org/securipax/.

[8] Palme Commission. Common Security. A Blueprint for Survival. New York, NY, USA: Simon \& Schuster; 1982.

[9] Richard J, Deepayan BR. The Human Security Framework and National Human Development Reports: that policy makers should address human insecurity by tackling developmental crises in the sub-region. There are lessons from other regions of the world that emphasise the urgency of the need to address the lingering issues of human insecurity and developmental crisis. While the relative failure of the Arab spring exemplified by the descent of Egypt and Syria into chaos and destruction may currently be a deterrent for a 'West African Spring,' the resentment for governments' inability to institutionalize human security and effectively address developmental crises to enhance the standard of living of the people is undeniable. The exposure of the teeming young and middle-aged class in the sub-region to the high standard of living in the developed world through increased access to conventional and social media raises important questions. How long can the region hold on before it descends into chaos and anarchy with grave humanitarian concerns for the entire sub-region if the status quo of underdevelopment and human insecurity does not change?

A Review of Experiences and Current Debates. NHDR Occasional Paper 5. 2006. Available from: http://hdr. undp.org/en/media/NHDR_Human_Security_GN.pdf.

[10] Tadjbakhsh S. Human Security: Concepts and Implication with an Application to Post-Intervention Challenges in Afghanistan. Centre d'études et de recherches internationals Sciences; 2005. Available from: http://www.sciencespo.fr/ceri/sites/sciencespo. fr.ceri/files/etude117_118.pdf.

[11] Obasi NK. The Importance of Human Security in West Africa. Workshop Human Security in West Africa: Challenges, Synergies and Action for a Regional Agenda. Sahel and West Africa Club/OECD; Lome, Togo, 26-28 March 2006.

[12] United Nations Development Programme 1994. Human Development Report-New Dimensions of Human Security. New York, NY, USA: Oxford University Press: 2001.

[13] Hussein KD, Gnisci JW. Security and Human Security: An Overview of Concepts and Initiatives. What Implications for West Africa? Paris, France: Organisation for Economic Co-operation and Development (OCED) Issues Paper; 2004.

[14] UNDP. Human Development Report. Oxford, UK: Oxford University Press; 1994.

[15] Leaning J, Arie S. Human Security: A Harvard Centre for Population and Development Studies Working Paper; 2001;11(3)1-63.

[16] Akokpari J. The Political Economy of Human Insecurity in Sub-Saharan Africa. V.R.F. Series, Institute of Developing Economies, Japan External Trade Organisation. 2007. No. 431; p. 10. Available from: http://www.ide.go.jp/English/Publish/Download/Vrf/p df/431.pdf.

[17] Pettman R. Human Security as Global Security: Reconceptualising Strategic Studies. Cambridge Review of International Affairs. 2005;18(1):137-150. 
[18] Annan K. We the Peoples: The Role of the United Nations in the 21st Century. New York, NY, USA: United Nations Department of Public Information; 2000.

[19] Fung IR. The Human Security Issue: Significance and Scale. Workshop Human Security in West Africa: Challenges, Synergies and Action for a Regional Agenda. Sahel and West Africa Club/OECD; Lome, Togo, 26-28 March 2006.

[20] Cilliers J. Human Security in Africa: A Conceptual Framework for Review. Nairobi, Kenya: A Monograph for the African Human Security Initiative; 2004.

[21] Commission on Human Security (CHS). Human Security Now: Protecting and Empowering People. New York, NY, USA: United Nations Publications; 2003.

[22] Prezelj I. Challenges in Conceptualizing and Providing Human Security. HUMSEC Journal Issue; 2008:2:1-21.

[23] Chen LC, Narasimhan V. Health And Human Security Pointing A Way Forward. 2002. Available from: https://sophieinstitute.files.wordpress.com/2013/ 09/health-and-human-security.pdf.

[24] Fuentes Julio CF, Brauch HG. The Human Security Network: Global North-South Coalition. In: Brauch HG, Spring US, Mesjasz C, Kameri-Mbote B, Behera NC, Chourou B, Krummenacher $H$. Facing Global Environmental Change: Environmental, Human, Energy, Food, Health and Water Security Concepts. Berlin and Heidelberg, Germany and New York, NY, USA: 2009. pp. 1013-1021.

[25] Kerr P. Human Security. In: Collins A, editor. Contemporary Security Studies. Oxford, UK: Oxford University Press; 2007.

[26] Bosold D, Werthes S. Human Security in Practice: Canadian and Japanese Experiences. Internationale Politik und Gesellschaft/International Politics and Society. 2005;1:84-101.

[27] Martin M, Owen T. The Second Generation of Human Security: Lessons from the United Nations and European Union Experience. International Affairs. 2010;86(1):211-224.

[28] Werthes S, Heaven C, Vollnhals S. Assessing Human Insecurity Worldwide: The Way to a Human (In)Security Index. Institute for Development and Peace. Report No. 102/2011.

[29] Thomas A. Development as Practice in a Liberal Capitalist World. Journal of International Development: 2000;12(6):773-787.

[30] Gore C. The Rise and Fall of the Washington Consensus as a Paradigm for Developing Countries. World Development. 2000;28(5):789-804.

[31] Sumner A. Meaning versus Measurement: Why do Economic Indicators of Poverty still predominate? International Development Studies. 2007;17(1):4-13.

[32] Hickey S, Mohan G. Relocating Participation within a Radical Politics of Development: Citizenship and Critical Modernism. Draft working paper prepared for conference on: Participation: From Tyranny to
Transformation? Exploring new approaches to participation in development. University of Manchester, Manchester, UK, 27-28 February 2003.

[33] Chambers R. Ideas for Development. Sussex: International Development Studies (IDS) Working Paper: 238. 2004.

[34] Kanbur R. What's Social Policy got to do with Economic Growth? 2006. Available from http://www. arts.cornell.edu/poverty/kanbur/SocPolEconGrowth.pdf.

[35] House W]. Conceptualising Development and the Need to Integrate Population Factors in Planning. UNFPA Country Support Team Office of the South Pacific Discussion Paper No 2. 1993.

[36] Soubbotina T, Sheram K. Beyond Economic Growth: Meeting the Challenges of Global Development. Washington, DC, USA: World Bank Publications; 2000.

[37] Shinoda H. The Concept of Human Security: Historical and Theoretical Implications. IPSHU English Research Report Series 19. 2004.

[38] Soubbotina TP, Sheram KA. Beyond economic growth: Meeting the challenges ofglobal development. Washington, DC, USA: World Bank; 2000.

[39] Africa Renewal. Africa's Vanishing Lake Chad: Action needed to counter an Ecological Catastrophe. 2012. Available from: http://www.un.org/africa renewal/magazine/april2012/africa\%E2\%80\%99s-van ishing-lake-chad.

[40] Adeleye O. Conflict and Violence in Africa: Causes, Sources and Types. 2011. Available from: https://www.transcend.org/tms/2011/02/conflict-andviolence-in-africa-causes-sources-and-types/.

[41] Brantlinger P. Victorians and Africans: The Genealogy of the Myth of the Dark Continent. Critical Inquiry; 1985;12(1):166-203.

[42] Olonisakin F. Conflict Dynamics in West Africa: Background Analysis for the UK Government's Africa Conflict Prevention Programme. CSDG Paper: 17. 2008.

[43] Annan N. Violent Conflicts and Civil Strife in West Africa: Causes, Challenges and Prospects. Stability. International Journal of Security and Development. 2014;3(1):Art.3. Available from: http://www. stabilityjournal.org/article/view/sta.da/173.

[44] Danish Refugee Council (DRC). Resurfacing Humanitarian Crisis in Guinea. Available from: http://www.trust.org/item/20130722142619-e72p9.

[45] UNDP. World Human Development Report 2001. Available from: http://hdr.undp.org/sites/default/ files/reports/262/hdr_2001_en.pdf.

[46] Bassey N. Trade and Human Rights in the Niger Delta. Pan African For Freedom and Justice. 2006. Available from: www.worldhunger.org/articles/ 06/africa/bassey.htm.

[47] Kitambo E. Human Security and Development. Ciudad Colón, Costa Rica: Universidad para la paz/ University of Peace Costa Rica; 2012. 